\title{
Commentary
}

\section{Jurisdictional Immunity and Infringement of Fundamental Labor Rights}

\author{
By Cedric Ryngaert, Professor of Public International Law, Utrecht \\ University, the Netherlands \& Frans Pennings, Professor of Labor Law \\ and Social Security Law, Utrecht University, the Netherlands
}

\section{Context}

The Supreme Court of the Netherlands judgment follows a request to overturn a judgment of the The Hague Court of Appeal, which had ruled that the European Patent Organization (EPO) could not rely on immunity on the grounds that it did not make available to claimants (trade unions) alternative methods of dispute settlement and that it had infringed on fundamental trade union rights. ${ }^{1}$

One of the measures disputed was the new Article 3oa of the Service Regulations of the EPO, which provides that notice of a strike shall be made to the EPO president. This notice shall at a minimum specify the grounds for the strike, as well as its scope, beginning, and duration. The measure, which provides that the president can define the duration of the strike, was seen as a restriction of the right to strike, which is not allowed under Article $G$ of the European Social Charter. Article $\mathrm{G}$ allows only restrictions prescribed by law that are necessary

1 Supreme Court of the Netherlands, European Patent Organisation \& the State of the Netherlands $v$ Vakbondsunie van het Europees Octrooibureau (VEOB) \& Staff Union of the European Patent Office (SUEPO), Case No. 15/02186, 20 January 2017, https://www.rechtspraak. nl/Organisatie-en-contact/Organisatie/Hoge-Raad-der-Nederlanden/Supreme-court-of-the -Netherlands/Documents/Verdict.pdf; Court of Appeal The Hague, Judgment of 17 February 2015, ECLI:NL:GHDHA:2015:255, http://deeplink.rechtspraak.nl/uitspraak?id=ECLI:NL:GHD HA:2015:255.

(C) RYNGAERT AND PENNINGS, 2017 | DOI 10.1163/24056901-00303011

This is an open access article distributed under the terms of the prevailing CC-BY-NC license at the time of publication 
to protect the rights and freedoms of others and public order, national security, and public health or morals. The ability of unions to decide for themselves when, why, and how long to strike is essential to their power, and without it the threat of a strike is meaningless. The requirement that strikes be restricted to conditions of employment was also disputed because strikes can concern other disputes than mentioned in Article 30a, such as health and safety. An additional issue was that the union's access to its members through the EPO email system was seriously restricted.

The Hague Court of Appeal argued that the EPO did not have jurisdictional immunity because the protection of the rights guaranteed by the European Convention on Human Rights (ECHR) is "manifestly deficient." The EPO argued that the protection was not manifestly deficient because individual EPO employees have the right to challenge, both at the EPO and before the ILO Administrative Tribunal (ILOAT), any restrictions of their right to strike. The Hague Court of Appeal decided, however, that this option could not be considered an effective remedy to enforce the rights of collective action and collective bargaining guaranteed by Article 11 ECHR. In this situation, granting immunity - to which the EPO was formally entitled under Article 3(1) of the Protocol to the European Patent Treaty on Privileges and Immunities-would amount to a disproportionate restriction of fundamental rights, in particular the right of access to a court under Article 6 ECHR.

The Supreme Court reviewed whether the proportionality requirement of Article $6 \mathrm{ECHR}$ had been satisfied in the sense that reasonable alternative ways were available to effectively protect the rights of vеов (the trade union) ensuing from Article 11(1) ECHR. The Court held that the employee representatives of the EPO, even if not the trade unions themselves, can use EPO judicial processes to seek protection of their rights under Article 11(1) ECHR. According to the Court, the trade unions had not established that employee representatives had no way to protect their right to collective bargaining before ILOAT.

\section{Analysis}

This judgment ends a drawn-out and highly public case that highlighted the poor employment conditions in the EPO, which included apparent restrictions of the employee rights to strike and to participate in EPO decision-making.

From a legal point of view, it is important that the Supreme Court affirmed that conferring immunity from jurisdiction should not affect the essence of a claimant's right of access to justice enshrined in Article 6 ECHR. This may be 
a basis for further development of the circumstances under which immunity from jurisdiction can be lifted.

According to a seminal European Court of Human Rights (ECtHR) decision in Waite and Kennedy, it follows from Article 6 that persons whose rights have allegedly been violated by an international organization shall have access to a remedial mechanism: before either a domestic court or a dispute-settlement mechanism made available by the organization itself, including an international labor tribunal. ${ }^{2}$ When such an alternative is reasonably available, States do not violate Article 6 E CHR when their domestic courts uphold the organization's immunity.

What is a reasonable alternative? In Waite and Kennedy, the ECtHR limited itself to holding that "[f]or the Court, a material factor in determining whether granting [an international organization] immunity from [domestic] jurisdiction is permissible under the Convention is whether the applicants had available to them reasonable alternative means to protect effectively their rights under the Convention" (para. 68). Dutch courts have interpreted this as not requiring protection identical to that normally offered by Article 6 ECHR, and have limited themselves to inquiring whether the essence of the right has not been compromised (see also the judgment of The Hague Court of Appeal). Given the autonomy of the organization, it needs to protect itself from undue interference by States, and that international organizations are not parties to the ECHR, this more "relaxed" review standard may be understandable (see also the report by Dutch Advisory Commission on Public International Law). ${ }^{3}$ Still, no explicit definition of the "essence" of Article 6 has been established, and perhaps one cannot even give a definition in the abstract: whether the core protections of Article 6 are undermined eventually depends on the facts and procedures at stake in a case. The present case was the first in which a collective labor case was brought against an international organization before a domestic court, so the Supreme Court had no precedent to rely on.

Although the Supreme Court mentions the manifest deficiency standard used by the The Hague Court of Appeal, it does not itself elaborate and uses instead the criterion of "serious alternatives." The manifest deficiency standard risks seriously eroding the protection offered by Article $6 \mathrm{ECHR}$, as it allows prima facie deficient procedures at the international organization to pass

2 European Court of Human Rights, Waite and Kennedy v Germany, Application No. 26083/94, 18 February 1999.

3 Advisory Committee on Issues of Public International Law, "Advisory Report on Responsibility of International Organisations," Report No. 27, The Hague, 2015. 
muster. This test has been criticized because it was devised by the ECtHR for Member State responsibility cases—not for immunity cases. ${ }^{4}$ In his advisory opinion on the EPO case before the Supreme Court, Advocate General Vlas rejected the criterion of manifest deficiency as the applicable review standard.

As noted, the Supreme Court does not mention manifest deficiency in its introductory restatement of the immunity principles or in the context of their application, so arguably the manifestly deficient standard is not the same as the "very essence" criterion based on Article 6 ECHR.

Instead, the Supreme Court applies a more traditional proportionality test and investigates whether any reasonable alternatives to procedures before domestic courts exist in this case. It held that because EPO employees could access the ILOAT to contest the EPO's practices and regulations, such an alternative does exist, even though only individual employees and not trade unions have access to the ILOAT. Accordingly, conferring jurisdictional immunity on the organization does not impair the essence of the trade union right of access to a court. The Supreme Court adds that the ECtHR considered (in Waite and Kennedy, para. 72) that the test of proportionality "cannot be applied in such a way as to compel an international organization to submit itself to national litigation in relation to employment conditions prescribed under national labor law. Otherwise the proper functioning of international organizations would be thwarted and this would run counter to the current trend towards extending and strengthening international cooperation."

\section{Right of Access to Court}

The trade unions had argued that denying access to ILOAT to the trade union means that no reasonable alternative in fact exists. Arguably, for realizing a collective right, such as the freedom of association and the right to strike, also the trade union itself, and not just individual employees should have the right of access. In the trade unions' view, the possibility for individual employees of EPO to challenge restrictions of the right to strike cannot be considered as an effective remedy to enforce the right of collective action and collective bargaining (para. 3.2.3).

The Supreme Court, however, does not follow this argument. It mentions in paragraph 5.5 that international law (such as ILO Conventions Nos. 87 and 98)

4 Cedric Ryngaert, "Immunities of International Organizations Before Domestic Courts: Reflections on the Collective Labour Case Against the European Patent Organization," Netherlands Yearbook of International Law 2015, pp. 393-408. 
does not secure a right for trade unions to go to court. ${ }^{5}$ Also from ECtHR case law, it follows, at least in the Court's view, that trade unions do not have a right to go to court (para. 5.6).

Still, whether the alternatives made available in this case are proportionate to denying trade unions' access to court with respect to disputes over limitations of the right to strike is yet to be investigated. It is arguably not enough to discuss case law that deals with access to court in individual disputes. Instead, one should take into account the actual—collective-rights at stake. It is relevant indeed that strikes and collective bargaining are always collective activities. Thus, if an individual strikes, they do not have protection under international law. Also in court, his or her claim that they do not want to work will not be seen or treated as a strike. Moreover, a strike is a suspension of a contractual obligation and therefore problematic for an individual in that they may easily lose their job.

In the case of a trade union going to court, those who are employed by the union rather than the EPO, being independent and not threatened by dismissal, effectively shield the EPO employees. That a representative organization can participate in judicial procedures is therefore a critical element of collective action. Regrettably, the Supreme Court does not appear to have applied a real proportionality test when stating that the litigation options of individuals compensate for unions' lack of access to court.

In addition, although Article 30 of the EPO Service Regulations recognizes the right to strike, this recognition is restricted to conditions of employment. Accordingly, it will be difficult for individuals to bring a case to the ILOAT regarding issues other than employment conditions. As the Supreme Court notes, that members of the trade union can contest the provisions laid down by the organization only after measures have been taken against them is not enough to justify the conclusion that the remedy available to them is not an effective remedy as defined in Article 13 ECHR. Thus, even if individuals can go to court only after they have been dismissed for a prohibited strike, the Supreme Court asserts that this remedy is still an effective one (para. 5.8). For individuals, in practice, the threshold for going to court when a collective right, such as that to strike, is involved is higher than for a trade union. It is therefore doubtful whether the considerations of the ECtHR in Waite and Kennedy judgment, which are related to a procedure on an individual right, can without modifications be applied to procedures as collective rights, as in the case of strike.

5 ILO Convention concerning Freedom of Association and Protection of the Right to Organise, 1948 (No. 87); ILO Convention concerning the Application of the Principles of the Right to Organise and to Bargain Collectively, 1949 (No. 98). 
Finally, the Supreme Court's observation that employee representatives have adequate methods of seeking protection of their rights on the grounds that the EPO and the ILOAT follow legal principles, including human rights, is hard to understand. After all, especially in the EPO Service Regulations, these fundamental labor rights are not followed. Why should we expect that when an issue is raised before the president, he will comply with human rights considerations?

\section{Conclusion}

Most immunity cases involving international organizations concern labor issues, such as exploitation of staff, inadequate procedures in case of intimidation, or - in this case-infringement of fundamental collective labor rights. Whether to grant immunity to organizations in such cases is challenging because a balance has to be struck between, on the one hand, the functioning of international organizations, which could be seriously hampered if all national law were applicable to them, and, on the other, the individual and collective rights of employees and their representatives. Given that an approach in one country can be problematic in another, courts are cautious about lifting an organization's immunity. The Dutch appeals court took a courageous stance, but to little avail in that the Dutch government refused to execute the judgment.

The Supreme Court was more cautious, deferring to the organization. Such an approach is not entirely warranted, however. By considering individual complaints before ILOAT as satisfying collective labor concerns, the Supreme Court does too little justice to the collective dimension of labor law, which requires that trade unions have a collective right to initiate legal proceedings. It is hoped that ILOAT allows such proceedings in the future. Only then should domestic courts characterize the procedure before ILOAT as a serious alternative that could justify immunity-based limitations of claimants' access to domestic courts. 